Jurnal Ekonomi dan Industri

e-ISSN : 2656-3169

Volume 20, No. 3, September-Desember 2019

p-ISSN : 0853-5248

\title{
PENGARUH PADAT KARYA TUNAI TERHADAP TINGKAT KEMISKINAN DI PEDESAAN PROV. JAWA BARAT DAN RIAU
}

\author{
Deni Herdiyana*) \\ *) Dosen Politeknik Keuangan Negara STAN \\ Jalan Bintaro Utama Sektor V, Bintaro Jaya, Tangerang Selatan. \\ Email : deni.herdiyana@pknstan.ac.id
}

\begin{abstract}
Cash for Work in the Village (CfWV) is one of the Village Fund revitalization programs conducted to empower rural communities, especially the poor and marginal, who are productive by prioritizing the use of resources, labor, and local technology to provide additional income, reduce poverty, and improve people's welfare. This study aims to analyze the implementation of CfWV policies in West Java and Riau Provinces. The method used is by conducting observations and interviews with stakeholders in the village which are categorized as Disadvantaged Villages or Very Disadvantaged Villages with a high number of poor people. In addition, a policy implementation approach which formulated by George C. Edward III was used to describe policy implementation variables, such as communication, resources, attitudes / dispositions, and bureaucratic structures. The findings of this study include: a tendency to decrease the spirit of mutual cooperation, the provision of a $30 \%$ minimum Working Day (HOK) Day is not fully suitable, and this program has not been able to permanently improve community welfare due to the temporary nature of its activities. Although this program is worth continuing, there needs to be some improvements, including the selection of activities that are more flexible in accordance with village needs and the expansion of community empowerment activities.
\end{abstract}

Keywords: cash for work, village funds, policy implementation

\section{PENDAHULUAN}

Dana desa merupakan salah satu terobosan dalam desentralisasi fiskal yang diharapkan dapat membantu mengatasi permasalahan mengenai ketimpangan pendapatan dan kemiskinan di perdesaan. Dana desa mulai dialokasikan dalam APBN pada TA 2015 dengan jumlah anggaran sebesar Rp. 20,7 triliun, dialokasikan ke 74.093 desa dengan ratarata setiap desa mendapatkan alokasi dana desa sebesar Rp280 juta. Pada tahun 2016, dana desa meningkat menjadi Rp. 46,98 triliun atau meningkat 126,24\% apabila dibandingkan dengan alokasi dana desa pada tahun 2015. Dana desa ini dialokasikan ke 74.754 desa, dengan rata-rata setiap desa mendapatkan alokasi dana desa sebesar Rp. 628 juta. Pada tahun 2017 alokasi dana desa kembali meningkat menjadi Rp. 60 triliun atau meningkat 27,71\% apabila dibandingkan dengan alokasi dana desa Tahun 2016. Kemudian angka Rp. 60 triliun dipertahankan di tahun 2018, selanjutnya meningkat menjadi Rp. 70 triliun pada tahun 2019.

Jika mengacu pada data yang dilansir oleh BPS, pada Maret 2013, penduduk miskin di perkotaan sebanyak 10,33 juta jiwa sedangkan jumlah penduduk miskin di perdesaan tercatat sebanyak 17,74 juta jiwa. Angka ini menurun pada Maret 2018 menjadi masingmasing sebesar 10,14 juta jiwa dan 15,81 juta jiwa. Artinya, terdapat penurunan penduduk miskin di perkotaan sebesar $1,79 \%$ dan di perdesaan sebesar $12,25 \%$. Grafik berikut menunjukkan jumlah penduduk miskin di perkotaan dan perdesaan pada tahun 2013-2018 (juta jiwa). 


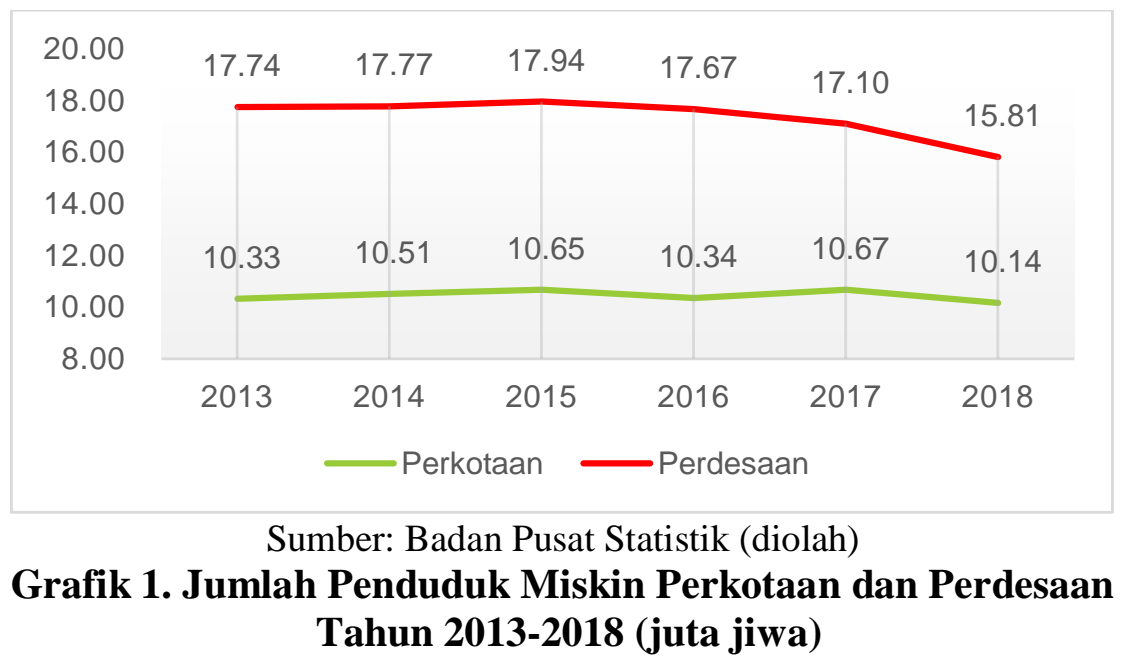

Secara persentase, pada Maret 2013 persentase penduduk miskin di perkotaan sebesar 8,39\% sedangkan jumlah penduduk miskin di perdesaan sebesar 14,32\%. Angka ini menurun pada Maret 2018 menjadi masing-masing sebesar 7,02\% dan 13,20\% juta jiwa. Artinya, terdapat penurunan penduduk miskin di perkotaan sebesar $1,37 \%$ dan di perdesaan sebesar $1,12 \%$. Grafik berikut menunjukkan persentase penduduk miskin di perkotaan dan perdesaan pada tahun 2013-2018 (\%).

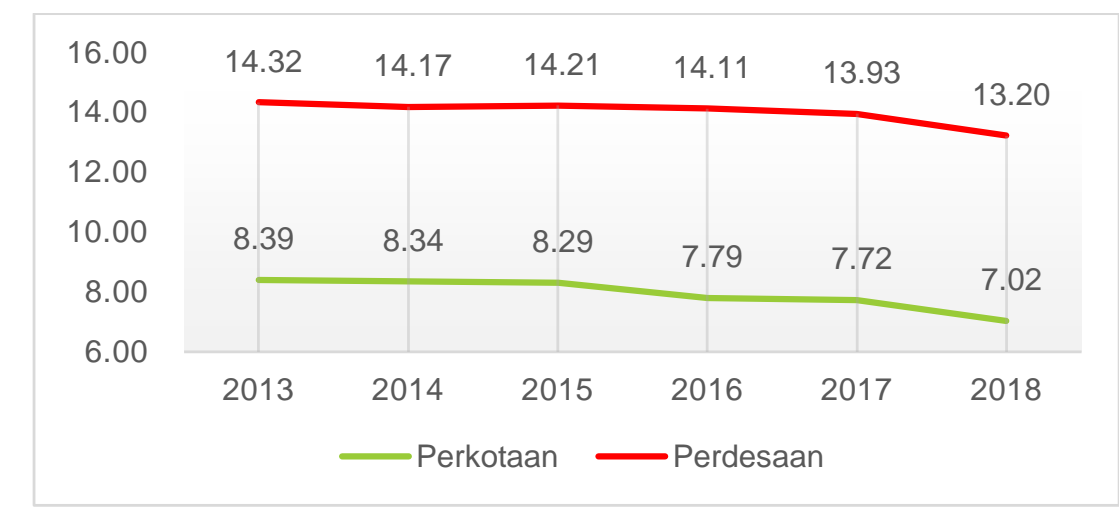

Sumber: Badan Pusat Statistik (diolah)

\section{Grafik 2. Persentase Penduduk Miskin Perkotaan dan Perdesaan Tahun 2013-2018 (\%)}

Namun di sisi lain, meskipun terdapat kecenderungan jumlah dan persentase penduduk miskin di perdesaan terus menurun, hal ini tidak diimbangi dengan pemerataan pendapatan penduduk. Distribusi pendapatan merupakan salah satu aspek kemiskignan yang perlu dilihat karena pada dasarnya merupakan ukuran kemiskinan relatif. Oleh karena data pendapatan sulit diperoleh, pengukuran distribusi pendapatan selama ini didekati dengan menggunakan data pengeluaran. Dalam hal ini, analisis distribusi pendapatan dilakukan dengan menggunakan data total pengeluaran rumah tangga sebagai pendekatan pendapatan yang bersumber dari data Susenas. Dalam analisis ini akan digunakan koefisien Gini untuk mengukur ketimpangan pengeluaran. Angka Gini yang semakin mendekati 1 (satu) menunjukkan semakin timpang.

Rasio Gini di daerah perkotaan pada 2018 tercatat sebesar 0,401 turun dibanding rasio Gini tahun 2013 yang sebesar 0,431. Sementara itu, rasio Gini di daerah perdesaan pada 2018 tercatat sebesar 0,324, naik jika dibandingkan dengan rasio Gini 2013 yang 
sebesar 0,320. Data ini menunjukkan bahwa terdapat gejala meningkatnya ketimpangan di perdesaan.

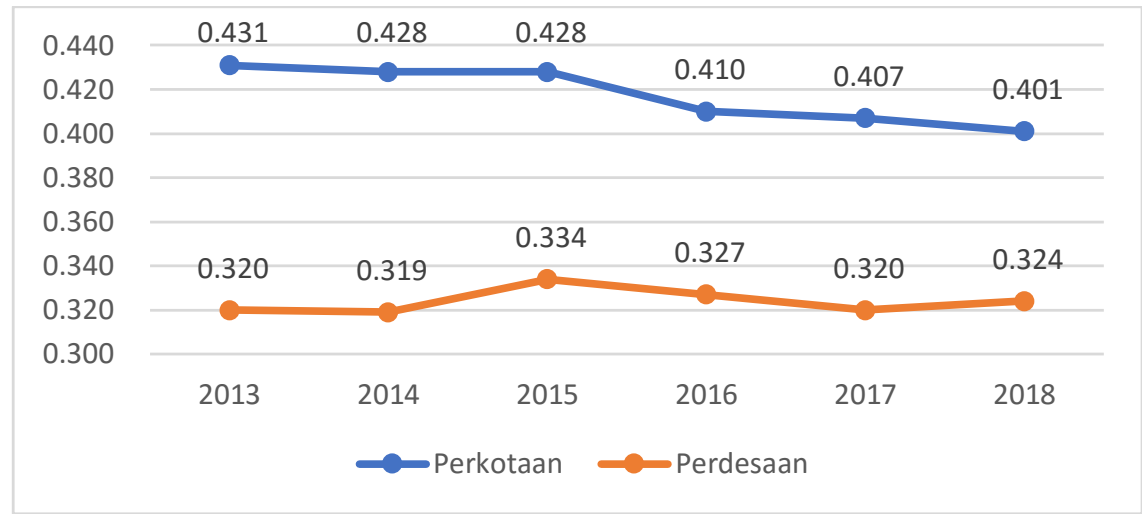

Sumber: Badan Pusat Statistik (diolah)

\section{Grafik 3. Rasio Gini Perkotaan dan Perdesaan Tahun 2013-2018}

Selain adanya kecenderungan ketimpangan pendapatan di perdesaan, terdapat pula indikasi meningkatnya jumlah tingkat pengangguran terbuka di perdesaan.

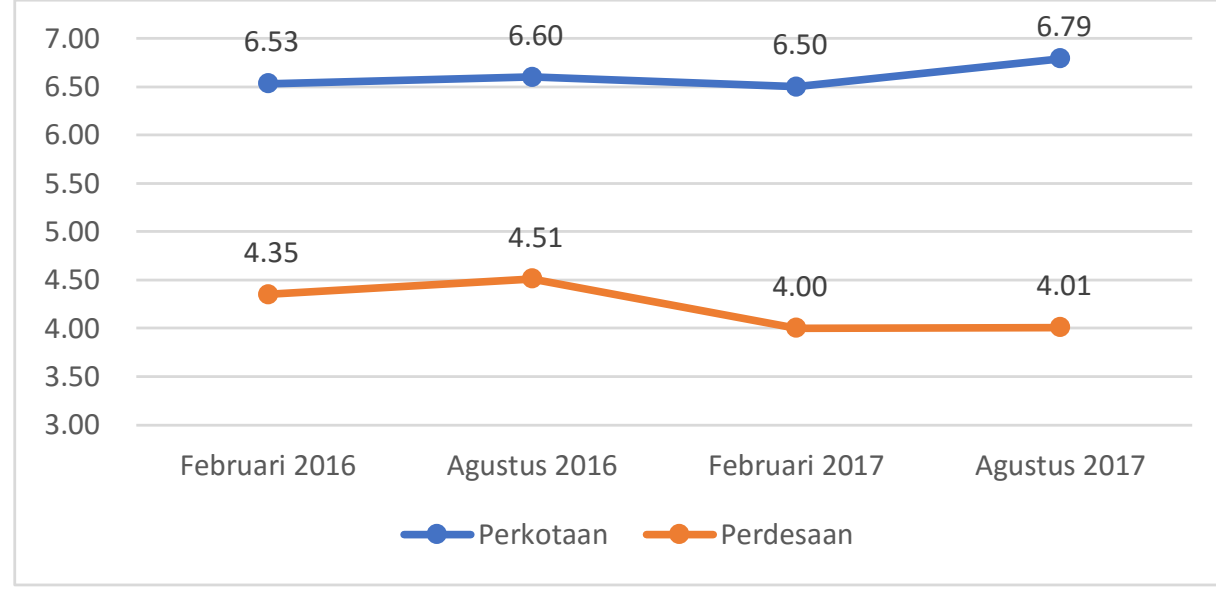

Sumber: Badan Pusat Statistik (diolah)

\section{Grafik 4. Tingkat Pengangguran Terbuka Perkotaan dan Perdesaan} Tahun 2016-2017 (\%)

Dari fenomena tersebut, muncullah pertanyaan seberapa efektifkah dana desa dalam mendukung peningkatan kesejahteraan di perdesaan. Dalam upaya mempercepat pemecahan masalah kemiskinan, kesenjangan dan masalah stunting di desa, mulai tahun 2018, Presiden menugaskan kepada kementerian/lembaga, pemerintah daerah provinsi, pemerintah daerah kabupaten/kota, dan pemerintah desa untuk melaksanakan program Padat Karya Tunai di Desa (PKTD) di seluruh desa. Khusus untuk penanganan masalah stunting akan diprioritaskan di 1.000 desa dalam 100 Kabupaten. Sebagai tindak lanjut arahan Presiden, telah diterbitkan Surat Keputusan Bersama (SKB) 4 Menteri tentang Penyelarasan dan Penguatan Kebijakan Percepatan Pelaksanaan Undang-Undang Nomor 6 Tahun 2014 tentang Desa.

Pelaksanaan PKTD ini merupakan refocusing penggunaan dana desa pada 3 (tiga) sampai dengan 5 (lima) jenis kegiatan sesuai dengan kebutuhan dan prioritas Desa, melalui koordinasi dengan kementerian terkait serta penggunaannya untuk kegiatan pembangunan desa paling sedikit $30 \%$ wajib digunakan untuk membayar upah masyarakat dalam rangka 
menciptakan lapangan kerja di desa. Adapun upah kerja dibayar secara harian atau mingguan dalam pelaksanaan kegiatan yang dibiayai dengan dana desa dengan mekanisme swakelola dan diupayakan tidak dikerjakan pada saat musim panen.

Berdasarkan uraian masalah yang dikemukakan tersebut, maka rumusan masalah dalam kajian ini adalah: 1). Apakah implementasi kebijakan Padat Karya Tunai di desa sudah sesuai dengan prinsip diadakannya program tersebut?. 2). Apakah implementasi kebijakan Padat Karya Tunai di Desa dapat mencapai tujuan yang telah diharapkan?. 3). Apa kendala dalam implementasi kebijakan Padat Karya Tunai di Desa?

\section{LANDASAN TEORI}

\section{Konsep Padat Karya Tunai (Cash for Work/CfW)}

Menurut Nagamatsu (2013), cash for work (CfW) adalah suatu metode untuk membantu korban yang terdampak bencana alam dengan cara mengikutsertakan dalam berbagai macam pekerjaan yang mencakup rekonstruksi dan pemulihan pasca bencana, serta membayar upah secara tunai, salah satunya adalah pasca bencana gempa bumi yang terjadi di Fukushima Jepang.

Sementara itu, nama lain dari $C f W$ adalah transfer tunai yang merupakan bentuk bantuan sosial yang fokus utamanya pada hal-hal sebagai berikut (Harvey dan DFID, 2005): 1). uang tunai yang diberikan kepada masing-masing rumah tangga, hal ini berbeda dengan komunitas masyarakat atau lembaga pemerintahan; 2). hibah tunai, PKT dan program kupon lebih daripada intervensi seperti monetisasi, keuangan mikro, asuransi, dukungan anggaran dan biaya keringanan; dan 3). uang tunai sebagai alternatif transfer natura seperti input pertanian, tempat tinggal dan barang-barang selain makanan sebagai alternatif distribusi bantuan makanan.

\section{Penelitian Terdahulu dalam Implementasi Cash for Work}

Pasca bencana tsunami Aceh yang terjadi pada tanggal 26 Desember 2004, organisasi kemanusiaan (Mercy Corps) mengadakan program Cash For Work (CfW) di 60 desa dan daerah perbukitan, sebanyak lebih dari 18.000 orang ikut serta berpartisipasi dalam program CfW dengan menghabiskan dana lebih dari USD 1 juta per bulan. Terkait pelaksanaan CfW tersebut, Doocy, et al (2006) telah melakukan penelitian melalui pengumpulan data secara rutin baik kuantitatif maupun kualitatif, dengan pengambilan sample dari 2 (dua) wilayah yaitu Banda Aceh dan Meulaboh. Hasil dari penelitian tersebut, mayoritas responden (93\%) beranggapan bahwa program CfW merupakan sumber utama penghasilan rumah tangga, serta sebanyak $91 \%$ partisipan menyatakan bahwa program CfW telah mendorong penduduk terlantar untuk kembali ke tempat tinggalnya. Lebih lanjut, pembayaran secara tunai dapat dilakukan secara aman dalam kondisi darurat dan implementasi CfW memberikan dampak positif baik bagi individu maupun setingkat komunitas dalam jangka pendek.

Program CfW juga pernah dilakukan dalam proses rekonstruksi pasca bencana gempa bumi Jepang Timur khususnya di prefektur Fukushima pada tahun 2011. Target program CfW tersebut adalah para pengangguran dan partisipan yang tidak ikut dalam program jejaring pengaman kerja seperti wirausaha, pekerja paruh waktu dan sementara. Berbeda dengan Program CfW yang dilaksanakan di negara berkembang, yang berpusat pada tenaga kerja manual, proyek Fukushima menyediakan berbagai macam pekerjaan termasuk pekerjaan kantor sehingga program CfW mempertimbangkan pengalaman sebelumnya dari para partisipan dan keterampilan yang dimiliki. Selanjutnya sebanyak $40 \%$ partisipan menyatakan bahwa upah yang diperoleh dari program CfW tersebut dijadikan sebagai penghasilan utama rumah tangga (Nagamatsu, 2013). 
Handa dan Davis telah melakukan penelitian atas pelaksanaan 6 (enam) program Conditional Cash Transfer (CCT) di Amerika Latin. Hasil penelitian tersebut menyimpulkan bahwa secara umum program tersebut sukses dilaksanakan, namun masih belum jelas terkait permasalahan dan efektifitas dari kegiatan CCT tersebut. Mereka beranggapan bahwa program CCT yang dijalankan hampir eksklusif hanya fokus pada perbaikan SDM untuk kalangan anak-anak, sehingga berdampak pada hilangnya kesempatan untuk meningkatkan kesejahteraan rumah tangga dan dalam konteks pembangunan pedesaan yang lebih luas. Selanjutnya pelaksanaan program CfW atau sejenisnya banyak dilakukan di negara-negara Afrika sebagaimana diobservasi oleh Kakwani, et al (2005) dengan melakukan penelitian terhadap 15 negara-negara di Afrika. Penelitian ini menyimpulkan bahwa untuk mengurangi rasio jumlah orang miskin adalah dengan meningkatkan pendapatan di antara rumah tangga miskin, sehingga perlu adanya alokasi dana CfW yang cukup besar dengan kisaran 2\% - 8\% dari PDB.

Lebih lanjut program CfW dapat menstimulus ekonomi lokal dengan memasukkan uang tunai ke dalam kawasan ekonomi yang telah habis sumber daya keuangannya. Penelitian selanjutnya dilakukan oleh beberapa peneliti (Lothike, 2005; Galuma, 2004; Harvey, 2005) dengan menyimpulkan bahwa komunitas lebih memilih bantuan uang daripada bantuan makanan, sehingga program CfW merupakan alternatif yang menarik baik bagi pihak penyedia maupun pihak penerima manfaat. Namun kesuksesan program CfW tergantung dari tujuan dan kemampuan manajemen pengelola program serta pelaksanaan di lapangan. Pada saat pelaksanaan CfW tidak dikelola dengan tepat, program CfW dapat mengganggu keadaan ekonomi lokal, upah menjadi naik, serta mendorong terjadinya pergeseran angkatan kerja (Cuny and Hill, 2005).

Adapun Barrientos dan DeJong melakukan penelitian secara komparatif terhadap efektivitas pengurangan kemiskinan dengan target anak-anak melalui program transfer tunai. Program transfer tunai tersebut fokus pada 3 (tiga) jenis program yang terdiri dari the Child Support Grant (Hibah Dukungan Anak) di Afrika Selatan, tunjangan keluarga di negara-negara transisi, dan ditargetkan pada Program CCT di Amerika Latin dan Karibia. Penelitian tersebut menemukan bahwa meskipun ada perbedaan dalam desain, program transfer tunai yang menargetkan anak-anak di rumah tangga miskin secara efektif dapat mengurangi kemiskinan dengan catatan pelaksanaan program tersebut dilengkapi dengan ketentuan yang jelas.

\section{Padat Karya Tunai di Desa (PKTD)}

Pelaksanaan Padat Karya Tunai di Desa (PKTD) merupakan salah satu program yang dicanangkan oleh 4 (empat) Menteri yang terdiri dari Menteri Dalam Negeri, Menteri Keuangan, Menteri Desa dan PDTT, dan Menteri PPN/Kepala Bappenas mulai tahun 2018 dengan ditetapkannnya Keputusan Bersama tentang Penyelarasan dan Penguatan Kebijakan Percepatan Pelaksanaan UU No.6/2014 tentang desa. Pelaksanaan PKTD ini merupakan refocusing penggunaan dana desa pada 3 (tiga) sampai dengan 5 (lima) jenis kegiatan sesuai dengan kebutuhan dan prioritas desa, melalui koordinasi dengan kementerian terkait serta penggunaannya untuk kegiatan pembangunan desa paling sedikit $30 \%$ wajib digunakan untuk membayar upah masyarakat dalam rangka menciptakan lapangan kerja di desa. Adapun upah kerja dibayar secara harian atau mingguan dalam pelaksanaan kegiatan yang dibiayai dengan dana desa dengan mekanisme swakelola dan diupayakan tidak dikerjakan pada saat musim panen.

PKT merupakan program yang dilakukan untuk memberdayakan masyarakat desa, khususnya yang miskin dan marginal, yang bersifat produktif dengan mengutamakan pemanfaatan sumber daya, tenaga kerja, dan teknologi lokal untuk memberikan tambahan 
upah/pendapatan, mengurangi kemiskinan, dan meningkatkan kesejahteraan rakyat. Adapun sasaran program PKT ini sebagai berikut: 1). Penganggur, yaitu penduduk baik dari kalangan laki-laki maupun perempuan serta bukan anak-anak, yang tidak memiliki pekerjaan, baik yang baru resign dari pekerjaan maupun yang sedang mencari pekerjaan. 2). Setengah Penganggur, yaitu penduduk yang bekerja di bawah jam kerja normal $(<35$ jam seminggu) atau petani yang mengalami paceklik dan menunggu masa tanam/panen. 3). Penduduk miskin, yaitu penduduk yang memiliki rata-rata pengeluaran per kapita selama sebulan berada di bawah garis kemiskinan. 4). Penduduk yang memiliki balita stunting (kekurangan gizi).

Untuk program Padat Karya Tunai 2018, pemerintah mengalokasikan sekitar Rp18 triliun atau 30 persen dari anggaran dana desa yang sebesar Rp. 60 triliun. Selain dari anggaran desa, Padat Karya Tunai juga memiliki sumber pendanaan lainnya. Sumber dana itu berasal dari anggaran kementerian/lembaga

\section{METODE PENEITIAN}

\section{Rancangan Penelitian}

Kajian ini menggunakan pendekatan deskriptif kualitatif dengan teknik survei dan diskusi/wawancara mendalam di daerah/desa sampel. Untuk tingkat kabupaten, diskusi/wawancara mendalam dilakukan dengan Kepala Dinas/aparatur DPMD Kabupaten dan pendamping desa tingkat kabupaten, dan untuk tingkat desa diskusi/wawancara mendalam dilakukan dengan Kepala Desa/aparatur desa, BPD, tenaga pendamping lokal desa dan tokoh masyarakat serta tenaga kerja penerima manfaat program PKT di desa. Penelitian ini juga menggunakan pendekatan studi kasus, salah satu pendekatan penelitian kualitatif yang bertujuan mendalami permasalahan pada kasus tertentu, sehingga hasilnya tidak bisa digeneralisir, tetapi hanya berlaku pada tempat dimana kasus tersebut terjadi.

Selain, itu untuk memperkaya studi lapangan, telah diedarkan kuesioner secara online. Instrumen dalam kuesioner mengacu pada variabel implementasi kebijakan berdasarkan pendekatan Edward III, terdiri dari 5 dimensi yaitu: Komunikasi, Sumber Daya, Sikap/Disposisi, Struktur Birokrasi, dan Implentasi. Terdapat 19 butir pernyataan dimana responden diminta untuk menyatakan sikap terhadap pernyataan tersebut dalam skala 1-5. Tabel berikut menguraikan variabel, dimensi, dan instrumen kajian.

Tabel 1. Variabel dan Indikator Kajian

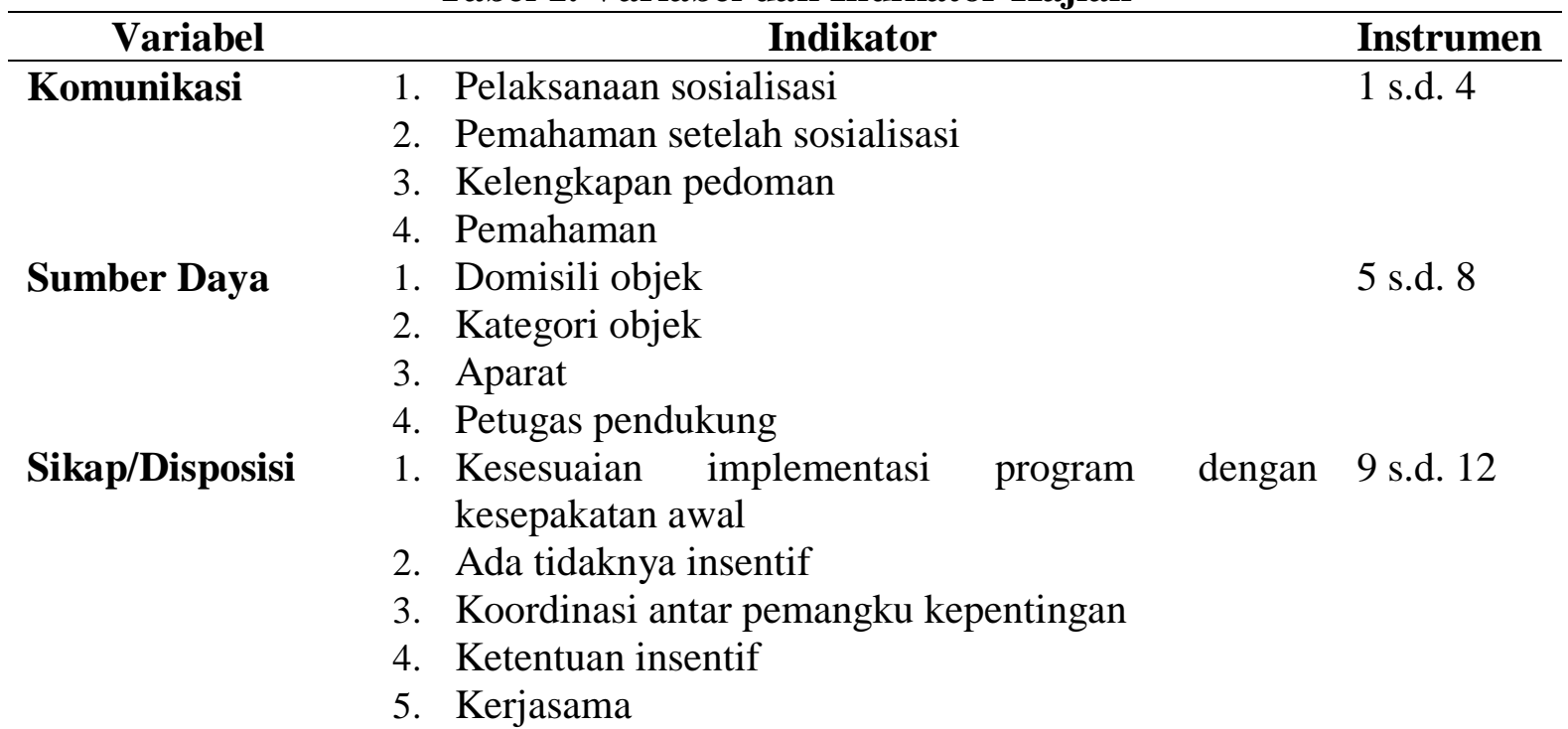




\begin{tabular}{|c|c|c|}
\hline Variabel & Indikator & Instrumen \\
\hline Struktur & 1. Pelaporan & 13 s.d. 14 \\
\hline Birokrasi & 2. Pengawasan & \\
\hline \multirow[t]{5}{*}{ Implementasi } & 1. Peningkatan pendapatan & 15 s.d. 19 \\
\hline & 2. Penurunan tingkat kemiskinan & \\
\hline & 3. Penurunan tingkat pengangguran & \\
\hline & 4. Kesesuaian dengan kebutuhan & \\
\hline & 5. Keberlanjutan program & \\
\hline
\end{tabular}

\section{Lokasi dan Jenis Kajian}

Kajian ini mengambil sampel di desa yang masuk kategori Desa Tertinggal (DT) atau Desa Sangat Tertinggal (DST) dengan Jumlah Penduduk Miskin (JPM) tinggi di wilayah Provinsi Jawa Barat dan Provinsi Riau. Sebagai pembanding, terdapat desa yang tidak termasuk klasifikasi DT/DST tapi dengan JPM tinggi yang dikunjungi untuk melihat secara langsung implementasi program Padat Karya Tunai.

\section{Sumber Data dan Informan}

Sumber Data primer adalah sumber data yang langsung diperoleh di lapangan penelitian dan dari orang-orang yang dianggap refresentatif dan dipilih secara purposif, sehingga bisa diperoleh data dan informasi mengenai permasalahan yang sedang diteliti. Responden yang dimasud tersebut adalah sebagai berikut : 1). Kepala Dinas Pemberdayaan Masyarakat dan Desa; 2). Kepala Bidang Pemberdayaan Masyarakat Desa, Dinas Pemberdayaan Masyarakat dan Desa; 3). Kasi Pengelolaan Keuangan Desa, Dinas Pemberdayaan Masyarakat dan Desa; 4). Camat beserta aparat; 5). Kepala Desa beserta perangkat desa; 6). Pendamping Desa; 7). Pendamping Lokal Desa; 8). Tim Pelaksana Kegiatan; 9). Tim Ahli; serta 10). Tokoh Masyarakat.

Sumber dan informan dipilih dengan kriteria dan pertimbangan sebagai berikut: 1). Para tokoh dipilih karena dianggap ikut serta dalam perencanaan dan pelaksanaan serta memperoleh dampak langsung proyek penggunaan Dana Desa. 2). Unsur pemerintah kabupeten dipilih karena mereka terlibat dalam perencanaan, pelaksanaan serta evaluasi penggunaan Dana Desa.

\section{HASIL PENELITIAN DAN PEMBAHASAN}

\section{Hasil Kunjungan Lapangan \\ Jawa Barat}

Provinsi Jawa Barat terdiri dari 27 kabupaten/kota, meliputi 18 kabupaten dan 9 kota. Luas wilayah Jawa Barat adalah $35.377,76 \mathrm{~km}^{2}$ dengan populasi 48,04 juta jiwa (data tahun 2017). Di provinsi ini, terdapat 5.319 desa yang tersebar di 18 kabupaten dan 1 kota. Jumlah penduduk miskin perdesaan di Jawa Barat pada tahun 2013 tercatat sebanyak 17,96 juta jiwa (11,96\%). Angka ini menurun menjadi 12,88 juta jiwa $(10,25 \%)$ pada tahun 2018. Jumlah desa yang masuk kategori desa maju sebanyak 38 desa $(0,71 \%)$, desa mandiri sebanyak 726 desa $(13,65 \%)$, desa berkembang sebanyak 3.140 desa $(25,47 \%)$, desa tertinggal sebanyak 1.355 desa $(25,47 \%)$, dan desa sangat tertinggal sebanyak 60 desa $(1,13 \%)$. 


\begin{tabular}{rlll}
\multicolumn{4}{c}{ Tabel 2. Sampel Desa Kunjungan di Jawa Barat } \\
\hline No. & \multicolumn{1}{c}{ Desa } & Kecamatan & Kabupaten \\
\hline 1 & Purasari & Leuwiliang & Bogor \\
2 & Margacinta & Leuwigoong & Garut \\
3 & Wanakaya & Haurgeulis & Indramayu \\
4 & Pamulihan & Cipicung & Kuningan \\
5 & Sukaraja & Ciawi Gebang & Kuningan \\
6 & Nagrog & Cipatujah & Tasikmalaya \\
7 & Pasirhalang & Cisarua & Bandung Barat \\
\hline
\end{tabular}

\section{Desa Purasari, Kec. Leuwiliang, Kab. Bogor}

Desa Purasari memiliki penduduk sebanyak 11.508 jiwa dengan jumlah penduduk miskin sebanyak 3.561 jiwa (30,94\%). Desa ini termasuk desa tertinggal dengan JPM tinggi. Total belanja pada APBDes Tahun 2018 sebesar Rp 2.459.452.080,-. Pada tahun 2018 mendapatkan dana desa sebesar Rp1.046.210.876,- dengan total nilai proyek yang bersumber dari dana desa untuk PKTD sebesar Rp1.046.210.876,- (100,00\%). Total nilai upah yang dialokasikan dari nilai proyek sebesar Rp95.000.000,- $(9,08 \%)$ dengan rata-rata upah sebesar Rp118.750,-/orang/hari.

Tabel 3. Rekapitulasi Proyek Berdasarkan Jenis Kegiatan di Desa Purasari

\begin{tabular}{ccccc}
\hline Proyek & Nilai Proyek & Jumlah Upah & Rata-rata \%HOK & Rata-rata Upah \\
\hline Jalan/Jembatan & 1.046 .210 .876 & 95.000 .000 & $13,71 \%$ & 118.750 \\
Total & $\mathbf{1 . 0 4 6 . 2 1 0 . 8 7 6}$ & $\mathbf{9 5 . 0 0 0 . 0 0 0}$ & $\mathbf{1 3 , 7 1 \%}$ & $\mathbf{1 1 8 . 7 5 0}$ \\
\hline
\end{tabular}

Di desa ini terdapat beberapa temuan, antara lain: 1). 30\% desa di Kabupaten Bogor merupakan desa mandiri. 2). Beberapa desa di Kabupaten Bogor mengalami penurunan alokasi dana desa berkisar penurunannya Rp.200 juta. 3). Sudah ada sosialisasi terkait PKT oleh DPMD kepada desa dengan mengumpulkan setiap desa di kantor kecamatan. Sosialisasi dilakukan per kecamatan. 4). Untuk desa yang masuk kategori desa maju dan mandiri sebagian dana desa digunakan untuk penambahan penyertaan modal BUMDes, dengan demikian untuk desa yang maju dan mandiri pelaksanaan PKT tidak maksimal. 5). Sudah ada pemantauan dan pengawasan terpadu terkait dengan penggunaan dana desa antara DPMD dengan BPKAD, Itjen dan Camat. 6). Terjadi perubahan RAB dan APBDes, karena program PKT muncul setelah penetapan APBDes.

\section{Desa Margacinta, Kec. Leuwigoong, Kab. Garut}

Desa Margacinta memiliki penduduk sebanyak 4.459 jiwa dengan jumlah penduduk miskin sebanyak 285 jiwa (6,39\%). Desa ini termasuk desa berkembang dengan Non-JPM tinggi. Total belanja pada APBDes Tahun 2018 sebesar Rp1.453.017.769,-. Pada tahun 2018 mendapatkan dana desa sebesar Rp834.790.000,- dengan total nilai proyek yang bersumber dari dana desa untuk PKTD sebesar Rp711.825.000,- $(85,27 \%)$. Total nilai upah yang dialokasikan dari nilai proyek sebesar Rp225.380.000,- $(31,66 \%)$ dengan rata-rata upah sebesar Rp78.278,-/orang/hari. 
Tabel 4. Rekapitulasi Proyek Berdasarkan Jenis Kegiatan di Desa Margacinta

\begin{tabular}{ccccc}
\hline Proyek & Nilai Proyek & Jumlah Upah & Rata-rata \%HOK & Rata-rata Upah \\
\hline Drainase & 140.098 .000 & 63.740 .000 & $44,42 \%$ & 82.713 \\
Jalan/Jembatan & 155.175 .000 & 25.440 .000 & $16,39 \%$ & 48.457 \\
Talud & 416.552 .000 & 136.200 .000 & $33,71 \%$ & 82.406 \\
Total & $\mathbf{7 1 1 . 8 2 5 . 0 0 0}$ & $\mathbf{2 2 5 . 3 8 0 . 0 0 0}$ & $\mathbf{3 5 , 5 6 \%}$ & $\mathbf{7 8 . 2 7 8}$ \\
\hline
\end{tabular}

Di desa ini terdapat beberapa temuan, antara lain: 1). PKT sudah sesuai dengan aturan SKB 4 menteri. 2). Pembangunan infrastruktur belum memerhatikan output dan outcome bagi masyarakat. 3). Dana desa sudah dialokasikan berdasarkan musyawarah desa dengan memperhatikan masukan $\mathrm{BPD} /$ masyarakat, namun tetap mempertimbangkan alokasi dana desa untuk per dusun. Hal ini dilakukan untuk pemeratan pembangunan antar dusun dan mengurangi ketimpangan/kecemburuan dusun apabila dana desa dilaksanakan hanya pada dusun tertentu saja. 4). Program Padat karya tunai muncul di akhir tahun 2017, dan langsung dilaksanakan pada awal tahun 2018. Pada saat itu, Peraturan Desa tentang APBDes dibanyak desa sudah ditetapkan. Untuk itu sebagian besar desa melakukan Perubahan APBDes dengan merubah RAB untuk mensinkronkan dengan pedoman PKT yang mengharuskan HOK 30 persen dari nilai kegiatan yang bersifat fisik. 5). Dalam rangka menindaklanjuti program PKT ini, daerah dalam hal ini DPMD telah melaksanakan sosialisasi disetiap kecamatan dalam bentuk rakor dengan melibatkan kepala desa/aparatur desa, tenaga pendamping desa/tenaga teknis desa serta camat/aparatur kecamatan. 6). Upaya yang dilakukan oleh DPMD utk percepatan pelaksanaan PKT di Desa: a). Membuat surat edaran Bupati ke desa, terkait dengan percepatan pelaksanaan PKT termasuk isinya penggunaan dana desa minimal $30 \%$ utk HOK. b). Memberikan sosialisasi kepada setisap desa dan pelaksanaan sosialisasi di tiap kecamatan. c). Peran pendamping sudah berjalan dengan baik, sudah saling bersinergy antara pemerintah daerah dengan tenaga pendamping dan desa. Ini ditandai dengan sudah adanya WA Group untuk saling berbagi solusi dalam memecahkan setiap permasalahan. 7). Budaya gotong royong masih kental di desa Margacinta, bisa saja di RAB dana desa utk betonisasi senilai Rp 100 juta utk $100 \mathrm{M}$, maka hasil akhirnya bisa menjadi $200 \mathrm{M}, 100 \mathrm{M}$ berdasarkan gotong royong dari masyarakat. 8). Melakukan koordinasi dengan camat, pendamping desa dan babinsa serta babinkantibmas dalam melaksanakan setiap kegiatan PKT, sehingga setiap pelaksanaan pekerjaan PKT dapat terlaksana dengan baik dan lancar.

\section{Desa Wanakaya, Kec. Haurgeulis, Kab. Indramayu}

Desa Wanakaya memiliki penduduk sebanyak 10.952 jiwa dengan jumlah penduduk miskin sebanyak 3.137 jiwa $(28,64 \%)$. Desa ini termasuk desa berkembang dengan JPM tinggi. Total belanja pada APBDes Tahun 2018 sebesar Rp 2.051.333.000,-. Pada tahun 2018 mendapatkan dana desa sebesar Rp 1.315.461.000,- dengan total nilai proyek yang bersumber dari dana desa untuk PKTD sebesar Rp 1.052.368.800,- (80,00\%). Total nilai upah yang dialokasikan dari nilai proyek sebesar Rp 315.570.000,- $(29,99 \%)$ dengan ratarata upah sebesar Rp92.162,-/orang/hari. 
Tabel 5. Rekapitulasi Proyek Berdasarkan Jenis Kegiatan di Desa Haurgeulis

\begin{tabular}{ccccc}
\hline Proyek & Nilai Proyek & Jumlah Upah & Rata-rata \%HOK & Rata-rata Upah \\
\hline Air Bersih dan Sanitasi & 6.000 .000 & 2.250 .000 & $37,50 \%$ & 93.750 \\
Drainase & 99.782 .000 & 98.820 .000 & $99,04 \%$ & 90.000 \\
Jalan/Jembatan & 831.673 .800 & 169.480 .000 & $25,38 \%$ & 91.697 \\
Rehabilitasi RTLH & 20.000 .000 & 3.200 .000 & $16,00 \%$ & 94.118 \\
Talud & 94.913 .000 & 41.820 .000 & $44,06 \%$ & 91.711 \\
Total & $\mathbf{1 . 0 5 2 . 3 6 8 . 8 0 0}$ & $\mathbf{3 1 5 . 5 7 0 . 0 0 0}$ & $\mathbf{4 1 , 2 3 \%}$ & $\mathbf{9 2 . 1 6 2}$ \\
\hline
\end{tabular}

Di desa ini terdapat beberapa temuan, antara lain: 1). HOK PKT sudah mencapai 30\%. 2). Di desa sudah ada APIP sebagai mitra desa. 3). Pendamping desa sangat membantu dalam program PKT. 4). Sudah ada indek biaya standar daerah untuk masingmasing wilayah, dan wilayah dibagi menjadi daerah sangat sulit, sulit dan wilayah mudah akses. Kategori Desa yang terletak pada kondisi geografis sangat sulit dan jauh dari ibukota kabupaten akan memiliki standar biaya yang lebih tinggi apabila dibandingkan dengan wilayah/desa yang letak geografisnya dekat dengan ibukota kabupaten. 5). Hanya saja dalam standar biaya daerah, faktor biaya/upah angkut (transportasi barang) belum dimasukkan, sehingga bagi daerah yang memiliki letak geografis sangat sulit dan jauh dari ibukota kabupaten akan mengeluarkan biaya transpor yang lebih besar, sehingga menjadi beban tambahan bagi desa tersebut.

\section{Desa. Pamulihan, Kec. Cipicung, Kab. Kuningan}

Desa Pamulihan memiliki penduduk sebanyak 3.495 jiwa dengan jumlah penduduk miskin sebanyak 514 jiwa $(14,71 \%)$. Desa ini termasuk desa berkembang dengan JPM tinggi. Total belanja pada APBDes Tahun 2018 sebesar Rp 2.051.333.000,-. Pada tahun 2018 mendapatkan dana desa sebesar Rp1.452.321.000,- dengan total nilai proyek yang bersumber dari dana desa untuk PKTD sebesar Rp931.589.000,- (57,69\%). Total nilai upah yang dialokasikan dari nilai proyek sebesar Rp127.320.000,- $(23,69 \%)$ dengan rata-rata upah sebesar Rp75.408,-/orang/hari.

Tabel 6. Rekapitulasi Proyek Berdasarkan Jenis Kegiatan di Desa Pamulihan

\begin{tabular}{ccccc}
\hline Proyek & $\begin{array}{c}\text { Nilai } \\
\text { Proyek }\end{array}$ & $\begin{array}{c}\text { Jumlah } \\
\text { Upah }\end{array}$ & $\begin{array}{c}\text { Rata-rata } \\
\text { \%HOK }\end{array}$ & $\begin{array}{c}\text { Rata-rata } \\
\text { Upah }\end{array}$ \\
\hline Air Bersih dan & 17.000 .000 & 1.750 .000 & $10,29 \%$ & 70.000 \\
Sanitasi & & & & \\
Irigasi & 40.605 .144 & 12.300 .000 & $30,29 \%$ & 74.545 \\
Lainnya & 131.273 .000 & 31.140 .000 & $28,20 \%$ & 78.012 \\
PAUD & 89.020 .000 & 22.890 .000 & $25,71 \%$ & 79.756 \\
Rehabilitasi RTLH & 50.000 .000 & 11.760 .000 & $23,52 \%$ & 75.871 \\
Sarpras Kesehatan & 44.762 .000 & 11.300 .000 & $25,24 \%$ & 80.714 \\
Sarpras Pendidikan & 164.782 .000 & 49.980 .000 & $30,33 \%$ & 79.586 \\
Total & $\mathbf{5 3 7 . 4 4 2 . 1 4 4}$ & $\mathbf{1 4 1 . 1 2 0 . 0 0 0}$ & $\mathbf{2 5 , 2 3 \%}$ & $\mathbf{7 7 . 0 6 2}$ \\
\hline
\end{tabular}

Di desa ini terdapat beberapa temuan, antara lain: 1). Upah PKT dibayarkan secara harian/mingguan, untuk laden sebesar Rp70.000-80.000/hari dan tukang sebesar Rp100.000/hari (untuk pembangunan rumah tidak layak huni, partisipan tidak mengambil upah tetapi disumbangkan untuk pembangunan rumah tidak layak huni lainnya). 2). Pendamping sangat membantu Pemerintahan Desa dalam pelaksanaan PKT. 
3). Masyarakat dilibatkan dalam perencanaan melalui musdes untuk memilih mana yang menjadi prioritas (di 5 dusun). 4). Kendala yang dihadapi: a). Terbatasnya anggaran untuk pembangunan rumah tidak layak huni dengan dana yang dibutuhkan sekitar Rp.30jt-40jt. b). Rumah tidak layak huni yang diperbaiki baru 3 rumah melalui swadaya gotong royong, sedangkan jumlah rumah yang tidak layak huni masih banyak sekitar 48 rumah (melalui rangking prioritas).

\section{Desa Sukaraja, Kec. Ciawi Gebang, Kab. Kuningan}

Desa Sukaraja memiliki penduduk sebanyak 6.118 jiwa dengan jumlah penduduk miskin sebanyak 1.798 jiwa (29,39\%). Desa ini termasuk desa berkembang dengan JPM tinggi. Total Belanja pada APBDes Tahun 2018 sebesar Rp1.809.693.000,-. Pada tahun 2018 mendapatkan dana desa sebesar Rp1.200.953.000,- dengan total nilai proyek yang bersumber dari dana desa untuk PKTD sebesar Rp765.119.850,- (63,71\%). Total nilai upah yang dialokasikan dari nilai proyek sebesar Rp149.794.500,- (19,50\%) dengan rata-rata upah sebesar Rp79.023,-/orang/hari.

Tabel 7. Rekapitulasi Proyek Berdasarkan Jenis Kegiatan di Desa Sukaraja

\begin{tabular}{ccccc}
\hline Proyek & $\begin{array}{c}\text { Nilai } \\
\text { Proyek }\end{array}$ & $\begin{array}{c}\text { Jumlah } \\
\text { Upah }\end{array}$ & $\begin{array}{c}\text { Rata-rata } \\
\text { \%HOK }\end{array}$ & $\begin{array}{c}\text { Rata-rata } \\
\text { Upah }\end{array}$ \\
\hline Air Bersih dan & 45.774 .000 & 12.000 .000 & $26,22 \%$ & 75.949 \\
Sanitasi & & & & \\
Drainase & 44.114 .400 & 11.200 .000 & $25,39 \%$ & 80.000 \\
Jalan/Jembatan & 481.796 .500 & 99.997 .500 & $20,76 \%$ & 77.759 \\
Rehabilitasi RTLH & 59.733 .150 & 8.000 .000 & $13,39 \%$ & 80.000 \\
Sarpras Kesehatan & 119.298 .800 & 14.800 .000 & $12,41 \%$ & 80.435 \\
Sarpras Olah Raga & 14.403 .000 & 3.200 .000 & $22,22 \%$ & 80.000 \\
Total & $\mathbf{7 6 5 . 1 1 9 . 8 5 0}$ & $\mathbf{1 4 9 . 1 9 7 . 5 0 0}$ & $\mathbf{2 0 , 0 6 \%}$ & $\mathbf{7 9 . 0 2 4}$ \\
\hline
\end{tabular}

Di desa ini terdapat beberapa temuan, antara lain: 1). Upah PKT dibayarkan secara mingguan, untuk laden sebesar Rp70.000/hari dan tukang sebesar Rp90.000/hari. 2). Pendamping sangat membantu Pemerintahan Desa dalam pelaksanaan PKT. 3). Kendala yang dihadapi: a). Peraturan teknis terkait PKT belum ada sehingga kesulitan untuk sinkronisasi, salah satunya perlu adanya keseragaman terkait penentuan besaran HOK. b). Siskeudes masih offline. c). Rincian kegiatan yang terdapat pada aplikasi OM SPAN terlalu banyak. d). Nilai kegotongroyongan semakin menurun semenjak adanya kegiatan PKT.

\section{Desa Nagrog, Kec. Cipatujah, Kab. Tasikmalaya}

Desa Nagrog memiliki penduduk sebanyak 3.423 jiwa dengan jumlah penduduk miskin sebanyak 683 jiwa (19,95\%). Desa ini termasuk desa tertinggal dengan JPM tinggi. Total belanja pada APBDes Tahun 2018 sebesar Rp1.984.164.313,-. Pada tahun 2018 mendapatkan dana desa sebesar Rp1.095.336.800,- dengan total nilai proyek yang bersumber dari dana desa untuk PKTD sebesar Rp988.334.740,- (90,23\%). Total nilai upah yang dialokasikan dari nilai proyek sebesar Rp306.958.000,- $(31,06 \%)$ dengan rata-rata upah sebesar Rp78.410,-/orang/hari. 
Tabel 8. Rekapitulasi Proyek Berdasarkan Jenis Kegiatan di Desa Nagrog

\begin{tabular}{ccccc}
\hline Proyek & Nilai Proyek & Jumlah Upah & Rata-rata \%HOK & Rata-rata Upah \\
\hline Drainase & 142.179 .800 & 52.914 .400 & $36,89 \%$ & 74.846 \\
Irigasi & 41.827 .100 & 13.060 .000 & $31,22 \%$ & 74.205 \\
Jalan/Jembatan & 632.404 .940 & 199.593 .600 & $33,34 \%$ & 81.789 \\
Talud & 171.922 .900 & 41.390 .000 & $24,07 \%$ & 76.225 \\
Total & $\mathbf{9 8 8 . 3 3 4 . 7 4 0}$ & $\mathbf{3 0 6 . 9 5 8 . 0 0 0}$ & $\mathbf{3 2 , 8 1 \%}$ & $\mathbf{7 8 . 4 1 0}$ \\
\hline
\end{tabular}

Di desa ini terdapat beberapa temuan, antara lain: 1). Sudah ada standar harga yang dikeluarkan oleh kepala daerah dengan terbitnya Peraturan Bupati terkait dengan standar biaya daerah. 2). Pelaksanaan kegiatan di Desa sudah merupakan hasil kesepakatan dari musyawarah desa, dan itu adalah kegiatan prioritas desa yang disepakati dalam musyawarah desa. 3). Harga2 di SBU daerah tidak mempertimbangkan jarak tempuh ke ibukota kabupaten dan kesulitan geografis desa. 4). Masih ada kebingungan dari aparatur desa terkait pelaksanaan PKT, 30\% dari masing-masing kegiatan atau 30\% adalah rata2 dari semua kegiatan fisik yang di danai dana desa. 5). Pembayaran upah di program PKT dibayarkan sudah sesuai dengan aturan yaitu secara mingguan dan dibayarkan pada hari Jumat. 6). Dengan adanya PKT menyebabkan budaya gotong royong mengalami penurunan, masyarakat hanya mau bekerja kalau ada pembayaran upah oleh Desa. 7). Pelaksanaan PKT, dilaksanakan secara campuran (gabungan antara PKT dengan gotong royong), sehingga hasil akhir (output) dari kegiatan biasanya melebihi dari rencana kegiatan yang sudah tercantum dalam RAB.

\section{Desa Pasirhalang, Kec. Cisarua, Kab. Bandung Barat}

Desa Pasirhalang memiliki penduduk sebanyak 6.117 jiwa dengan jumlah penduduk miskin sebanyak 700 jiwa $(11,44 \%)$. Desa ini termasuk desa maju dengan JPM tinggi. Total belanja pada APBDes Tahun 2018 sebesar Rp2.074.514.254,-. Pada tahun 2018 mendapatkan dana desa sebesar Rp 2.074.514.254,- dengan total nilai proyek yang bersumber dari dana desa untuk PKTD sebesar Rp772.309.700,- (86,64\%). Total nilai upah yang dialokasikan dari nilai proyek sebesar Rp239.500.000,- $(31,01 \%)$ dengan rata-rata upah sebesar Rp105.275,-/orang/hari.

Tabel 9. Rekapitulasi Proyek Berdasarkan Jenis Kegiatan di Desa Pasirhalang

\begin{tabular}{ccccc}
\hline Proyek & Nilai Proyek & Jumlah Upah & Rata-rata \%HOK & Rata-rata Upah \\
\hline Jalan/Jembatan & 772.309 .700 & 239.500 .000 & $31,01 \%$ & 105.275 \\
Total & $\mathbf{7 7 2 . 3 0 9 . 7 0 0}$ & $\mathbf{2 3 9 . 5 0 0 . 0 0 0}$ & $\mathbf{3 1 , 0 1 \%}$ & $\mathbf{1 0 5 . 2 7 5}$ \\
\hline
\end{tabular}

Di desa ini terdapat beberapa temuan, antara lain: 1). Kesulitan untuk menyusun RAB dengan refocusing HOK minimal 30\%. 2). HOK 30\% tidak sesuai dengan desa yang maju dan dekat dengan perkotaan. 3). Kesulitan untuk mencari tenaga ahli dalam pelaksanaan PKT. 4). Kesulitan dalam pengelolaan aplikasi OMSPAN karena terdapat beberapa referensi kegiatan yang mirip. 5). Terdapat kecenderungan semangat gotong royong masyarakat sedikit berkurang setelah adanya program PKT. 6). Kesulitan dalam penyusunan laporan pertanggungjawaban untuk pencairan alokasi Dana Desa Tahap ke-3 dikarenakan banyak desa yang merubah APBDes. 7). Ada kesulitan untuk menyusun Laporan PKT berdasarkan PMK 225. 


\section{Riau}

Provinsi Riau terdiri dari 12 kabupaten/kota, meliputi 10 kabupaten dan 2 kota. Luas wilayah Riau adalah $87.023,66 \mathrm{~km}^{2}$ dengan populasi 6,66 juta jiwa (data tahun 2017). Di provinsi ini, terdapat 1.592 desa yang tersebar di 10 kabupaten. Jumlah penduduk miskin perdesaan di Riau pada tahun 2013 tercatat sebanyak 320 ribu jiwa (8,73\%). Angka ini meningkat menjadi 330 ribu jiwa $(8,09 \%)$ pada tahun 2018. Jumlah desa yang masuk kategori desa mandiri sebanyak 9 desa $(0,57 \%)$, desa berkembang sebanyak 275 desa $(17,27 \%)$, desa tertinggal sebanyak 885 desa $(55,59 \%)$, dan desa sangat tertinggal sebanyak 423 desa $(26,57 \%)$. Di provinsi ini tidak terdapat desa dengan kategori desa maju.

\section{Tabel 13. Sampel Desa Kunjungan di Riau}

\begin{tabular}{rcll}
\hline No. & \multicolumn{1}{c}{ Desa } & \multicolumn{1}{c}{ Kecamatan } & Kabupaten \\
\hline 1 & Karya Indah & Tapung & Kampar \\
2 & Rantau Baru & Pangkalan Kerinci & Pelalawan \\
\hline
\end{tabular}

\section{Desa Karya Indah, Kec. Tapung, Kab. Kampar}

Desa Karya Indah memiliki penduduk sebanyak 6.928 jiwa dengan jumlah penduduk miskin sebanyak 309 jiwa (4,46\%). Desa ini termasuk desa tertinggal dengan JPM tinggi. Total belanja pada APBDes Tahun 2018 sebesar Rp1.902.547.000,-. Pada tahun 2018 mendapatkan dana desa sebesar Rp796.798.000,- dengan total nilai proyek yang bersumber dari dana desa untuk PKTD sebesar Rp691.650.200,- (86,80\%). Total nilai upah yang dialokasikan dari nilai proyek sebesar Rp146.620.000,- $(21,20 \%)$ dengan rata-rata upah sebesar Rp106.080,-/orang/hari.

Tabel 14. Rekapitulasi Proyek Berdasarkan Jenis Kegiatan di Desa Karya Indah

\begin{tabular}{ccccc}
\hline Proyek & $\begin{array}{c}\text { Nilai } \\
\text { Proyek }\end{array}$ & $\begin{array}{c}\text { Jumlah } \\
\text { Upah }\end{array}$ & $\begin{array}{c}\text { Rata-rata } \\
\text { \%HOK }\end{array}$ & $\begin{array}{c}\text { Rata-rata } \\
\text { Upah }\end{array}$ \\
\hline Jalan/Jembatan & 461.035 .200 & 73.020 .000 & $15,84 \%$ & 103.574 \\
Lainnya & 124.114 .000 & 41.520 .000 & $33,45 \%$ & 105.918 \\
Sarpras & 106.501 .000 & 32.080 .000 & $30,12 \%$ & 108.746 \\
Kesehatan & & & & \\
Total & $\mathbf{6 9 1 . 6 5 0 . 2 0 0}$ & $\mathbf{1 4 6 . 6 2 0 . 0 0 0}$ & $\mathbf{2 6 , 4 7 \%}$ & $\mathbf{1 0 6 . 0 8 0}$ \\
\hline
\end{tabular}

Di desa ini terdapat beberapa temuan, antara lain: 1). Alokasi upah kerja di program PKT masih belum mencapai 30\%, karena pada saat program PKT turun, APBDes sdh ditetapkan. Kami dan masyarakat berdasarkan musdes tidak merubah RAB dan tetap menggunakan RAB sesuai APBDes. 2). Persentase PKT di Desa Karya Indah rata2 26\%. 3). Apabila PKT belum mencapai 30\% apakah ada sanksinya. 4). Saat ini pengalokasian dana desa dibagi secara merata antar dusun, bukan perdasarkan prioritas desa. Sebaiknya alokasi dana desa berdasarkan prioritas kegiatan yang sudah disepakati dan ditetapkan dalam musdes. 5). Pendamping lokal desa belum masksimal, karena satu orang pendamping lokal desa membawahi 3 atau 4 desa. Perlu ada penambahan jumlah personil pendamping lokal desa, sehingga setiap desa memiliki pendamping desa. 6). Penghasilan pendamping lokal desa belum mendapatkan penghasilan yang memadai, masih jauh dibawah UMR. 7). Penggunaan/pemakaian Tenaga kerja dalam rangka PKT dilakukan pendataan terlebih dahulu dari masing-masing RT dan pelaksanaan PKT dilakukan secara bergilir, sehingga semua tenaga kerja yang tidak bekerja di Desa memiliki bagian yang 
sama. 8). Usulan masyarakat (BPD): a). Dana Desa utk proteksi kebakaran. b). Apakah dana desa bisa digunakan utk membangun sarana ibadah. c). Dana Desa dapat digunakan utk pendanaan bencana alam. d). Dana Desa dapat digunakan untuk dana bantuan sosial kepada masyarakat.

\section{Desa Rantau Baru, Kec. Pangkalan Kerinci, Kab. Pelalawan}

Desa Rantau Baru memiliki penduduk sebanyak 609 jiwa dengan jumlah penduduk miskin sebanyak 87 jiwa (14,29\%). Desa ini termasuk desa tertinggal dengan JPM tinggi. Total belanja pada APBDes Tahun 2018 sebesar Rp1.908.660.000,-. Pada tahun 2018 mendapatkan dana desa sebesar Rp780.180.000,- dengan total nilai proyek yang bersumber dari dana desa untuk PKTD sebesar Rp592.680.000,- (75,97\%). Total nilai upah yang dialokasikan dari nilai proyek sebesar Rp151.351.000,- (25,54\%) dengan rata-rata upah sebesar Rp106.080,-/orang/hari.

Tabel 15. Rekapitulasi Proyek Berdasarkan Jenis Kegiatan di Desa Rantau Baru

\begin{tabular}{ccccc}
\hline Proyek & $\begin{array}{c}\text { Nilai } \\
\text { Proyek }\end{array}$ & $\begin{array}{c}\text { Jumlah } \\
\text { Upah }\end{array}$ & $\begin{array}{c}\text { Rata-rata } \\
\text { \%HOK }\end{array}$ & $\begin{array}{c}\text { Rata-rata } \\
\text { Upah }\end{array}$ \\
\hline Air Bersih dan & 82.000 .000 & 23.333 .000 & $28,45 \%$ & 96.817 \\
Sanitasi & & & & \\
Jalan/Jembatan & 180.000 .000 & 31.134 .000 & $17,30 \%$ & 90.770 \\
Sarpras Kesehatan & 188.680 .000 & 55.101 .000 & $29,20 \%$ & 99.821 \\
Sarpras Olah Raga & 142.000 .000 & 41.783 .000 & $29,42 \%$ & 94.746 \\
Total & $\mathbf{5 9 2 . 6 8 0 . 0 0 0}$ & $\mathbf{1 5 1 . 3 5 1 . 0 0 0}$ & $\mathbf{2 6 , 0 9 \%}$ & $\mathbf{9 5 . 5 3 8}$ \\
\hline
\end{tabular}

Di desa ini terdapat beberapa temuan, antara lain: 1). Program PKT muncul setelah APBDes ditetapkan sehingga menyebabkan perubahan RAB dan dengan adanya perubahan RAB maka mengorbankan kegiatan prioritas desa yaitu pembangunan jembatan penghubung desa dengan ibukota kabupaten, karena pembangunan jembatan menggunakan mesin traktor dan sedikit tenaga kerja manusia. 2). Upah yang ditetapkan dalam RAB terlalu kecil apabila dibandingkan dengan upah riel yang terjadi dilapangan (yang diterima masyarakat yang sebagian besar adalah pekerja dikebun karet dan kebun kelapa sawit), sehingga masyarakat menjadi enggan untuk ikut kegiatan PKT. 3). Solusi yang diberikan oleh kepala desa adalah pelaksanaan PKT dilaksanakan setelah penduduk/masyarakat melaksanakan kerja di kebun karet dan biasanya dilaksanakan pada malam hari. 4). Sulit mencari pekerja yang bersedia untuk melaksanakan kegiatan PKT sehingga akhirnya kepala desa menggunakan tenaga kerja yang berasal dari luar desa. 5). Penggunaan tenaga kerja masyarakat lokal, sulit dilaksanakan pada daerah perkebunan. Karena upah kerja kecil dibandingkan upah kerja perkebunan.

\section{KESIMPULAN DAN REKOMENDASI}

\section{Kesimpulan}

1). Program PKT tidak sesuai apabila dilaksanakan di desa yang sudah mandiri dan maju dikarenakan fasilitas infrastruktur desa sudah tersedia dan memadai, sehingga tidak efektif apabila program PKT tetap dilaksanakan di desa mandiri dan maju tersebut. 2). Partisipan Program PKT belum sepenuhnya dapat mengakomodir masyarakat desa yang miskin, diantaranya terdapat masyarakat miskin yang sudah tidak bisa bekerja lagi (manula)/masyarakat miskin yang tidak memiliki kemampuan/keahlian untuk turut serta dalam program PKT. 3). Pemerintah Pusat/Daerah telah melakukan sosalisasi sebelum 
penerapan program PKT. Sosialisasi tersebut telah memberikan kejelasan program secara cukup yang disertai dengan pedoman yang lengkap. Namun di sebagian kecil desa sampel, terdapat keluhan akan minimnya pedoman teknis lanjutan terkait pelaksanaan PKT yang belum sesuai dengan kebutuhan. 4). Masyarakat yang terlibat dalam program PKT ini adalah yang termasuk dalam kategori miskin, tidak bekerja, dan merupakan warga setempat. Namun di beberapa kasus, terdapat masyarakat yang tidak masuk kategori miskin tetapi ikut serta dalam program PKT dikarenakan adanya faktor 'kedekatan' dengan kepala desa/aparatur desa. 5). Pendamping Lokal Desa (PLD) telah berperan secara optimal dalam program PKT, meskipun terdapat beberapa kendala diantaranya adalah sebagai berikut: a). Domisili PLD yang jauh dari desa mengakibatkan terhambatnya mobilitas PLD dalam melaksanakan pendampingan ke desa tersebut, b). Gaji/penghasilan PLD yang relatif kecil sehingga tidak mencukupi untuk biaya transportasi/operasional, c). Di beberapa desa terdapat kecenderungan aparatur desa masih mengandalkan PLD untuk mengerjakan tugas yang seharusnya dikerjakan oleh aparatur desa. 6). Para pekerja penerima manfaat program PKT pada umumnya telah mendapatkan upah sesuai dengan standar biaya yang ditetapkan oleh daerah, namun dibeberapa daerah yang memiliki biaya hidup tinggi upah tersebut relatif tidak mencukupi. 7). Ketentuan Hari Orang Kerja (HOK) sebesar 30\% kurang cocok bagi sebagian daerah, terutama bagi daerah yang: a). memiliki infrastruktur yang relatif baik, b). berkarakteristik perairan, atau c). membutuhkan sarana/prasarana yang pembangunnya memerlukan keahlian khusus dan/atau alat berat (misal: pembangunan embung, jalan hotmix). 8). Peran masyarakat dan aparatur dalam mengawasi pelaksanaan program PKT masih wajar dan tidak berlebihan. Namun di beberapa desa terdapat keluhan terhadap maraknya campur tangan yang tidak wajar dari Lembaga Swadaya Masyarakat (LSM) dalam pengelolaan program ini. 9). Program ini belum dapat meningkatkan kesejahteraan masyarakat secara permanen karena sifat kegiatannya yang temporer. Setelah kegiatan PKT selesai, masyarakat yang tidak memiliki pekerjaan tetap akan kembali menganggur. 10). Dampak pelaksanaan Program PKT secara ekonomi sudah terlihat secara langsung di beberapa desa sample, sebagai contoh pada saat partisipan penerima manfaat program PKT menerima upah/ gajian, langsung dibelanjakan untuk kebutuhan sehari-hari.

\section{Rekomendasi}

1). Sebaiknya program PKT difokuskan pada desa yang masuk dalam kategori Desa Tertinggal (DT) dan Desa Sangat Tertinggal (DST) dengan Jumlah Penduduk Miskin (JPM) tinggi, karena kondisi infrastruktur di desa tersebut masih sangat terbatas dan masih memerlukan perbaikan serta tambahan infrastruktur. Sedangkan untuk desa mandiri/maju, pelaksanaan kegiatan yang bersumber dari Dana Desa sebaiknya lebih difokuskan untuk kegiatan/program mengenai pemberdayaan masyarakat desa. 2). Perlu dilakukan sosialisasi yang lebih intensif oleh Pemda kabupaten/kota serta perlu adanya penetapan pedoman teknis lanjutan yang ditetapkan oleh Pemerintah Daerah Kabupaten/Kota untuk melengkapi pedoman umum Program PKT yang sudah ditetapkan oleh Pemerintah Pusat. 3). Untuk menjaga pelaksanaan PKT yang transparan dan tepat sasaran, perlu adanya monitoring, evaluasi dan pengawasan dari masyarakat setempat dan Inspektorat Daerah Kabupaten setempat. 4). Perlu adanya pemutakhiran database terkait data IDM dan jumlah penduduk miskin di perdesaan agar lebih akurat dan valid dalam pemetaaan kondisi/kategori desa. 5). Perlu adanya keterlibatan masyarakat secara holistik dalam Musdes agar tidak ada masyarakat yang dirugikan dalam pelaksanaan kegiatan Program PKT. 6). Perlu ditinjau kembali dan penyesuaian Standar Biaya Daerah (SBD) untuk membayar partisipan Program PKT agar sesuai dengan upah riil yang berlaku di daerah 
tersebut. 7). Sebaiknya ketentuan mengenai HOK sebesar $30 \%$ agar tidak rigid, agar ketentuan $30 \%$ tersebut dapat dikecualikan bagi desa-desa yang sudah memiliki infrastruktur yang relatif baik, berkarakteristik perairan, dan desa-desa yang membutuhkan sarana/prasarana yang pembangunannya memerlukan keahlian khusus dan/atau alat berat (misal: pembangunan embung, jalan hotmix). 8). Perlu peran aktif dari babinsa dan bhabinkamtibmas dalam mengatasi maraknya campur tangan yang tidak wajar dari Lembaga Swadaya Masyarakat (LSM) dalam pengelolaan program PKT. 9). Perlu adanya pengalihan program PKT yang sampai saat ini fokus pada pembangunan sarana dan prasarana desa menjadi program pemberdayaan masyarakat desa. Dengan program pemberdayaan masyarakat desa maka masyarakat akan dibekali dan dilatih dengan berbagai keahlian yang dapat digunakan untuk meningkatkan kapasitas/kemampuannya sehingga nantinya dapat membuka usaha sendiri dan bahkan dapat membuka lapangan pekerjaan baru bagi masyarakat lainnya sehingga pengangguran di desa dapat dikurangi dan masyarakat desa memiliki mata pencaharian secara berkesinambungan. 10). Program PKT perlu ditindaklanjuti dan dilaksanakan pada tahun berikutnya, namun dengan catatan perlu adanya perbaikan dalam tahap implementasi program PKT. Untuk itu, perlu mendorong Kementerian Desa dan PDTT untuk mempertajaman kebijakan prioritas penggunaan dana desa agar lebih dapat memberdayakan masyarakat desa dalam rangka untuk mengurangi kemiskinan.

\section{DAFTAR PUSTAKA}

Badan Pusat Statistik. (2018). Provinsi Jawa Barat dalam Angka. Bandung: Badan Pusat Statistik.

Badan Pusat Statistik. (2018). Provinsi Riau dalam Angka. Pekanbaru: Badan Pusat Statistik.

Barrientos, A., \& DeJong, J. (2004). Child Poverty and Cash Transfers (Childhood Poverty Research and Policy Centre Report No. 4) . London: Save the Children.

Department for International Development (DFID). (2005). Social Transfers and Chronic Poverty: Emerging Evidence and the Challenge Ahead. A DFID Practice Paper. London: Department for International Development (DFID).

Doocy, S., Gabriel, M., Collins, S., \& Robinson, C. (2006). Implementing Cash for Work Programmes in Post-Tsunami Aceh: Experiences and Lessons Learned. Disasters, 30(3), 277-293.

Guluma, Y. (2004). Studies on Alternatives to Food Aid: Case Study DRC: Cash for Work Projects. London: Save the Children.

Handa, S., \& Davis , B. (2006). The Experience of Conditional Cash Transfers in Latin America and the Caribbean. Development Policy Review, 24(5), 513-536.

Harvey, P. (2005). Cash and Vouchers in Emergencies. Humanitarian Policy Group Discussion Paper. London: Overseas Development Institute.

Kakwani, N., Soares, F., \& Son , S. (2005). Conditional Cash Transfers in African Countries: UNDP Research Project Report . New York: United Nations Development Programme (UNDP).

Lothike, E. (2005). Cash for Work in Emergencies: Turkana 2001 and 2003. Cash: A New Currency for Emergency Interventions? Lessons from Recent Experience in Nairobi, Kenya. 
Menteri Keuangan, Menteri Desa dan Pembangunan Daerah Tertinggal dan Transmigrasi, Menteri Dalam Negeri, dan Menteri Perencanaan Pembangunan Nasional/Badan Perencanaan Pembangunan Nasional. (2017). Keputusan Bersama tentang Penyelarasan dan Penguatan Kebijakan Percepatan Pelaksanaan Undang-Undang Nomor 6 Tahun 2014 tentang Desa. Jakarta.

Nagamatsu, S. (2013). Are Cash for Work (CfW) Programs Effective to Promote Disaster Recovery? Evidence from the Case of Fukushima Prefecture. Journal of Disaster Research, 9(2).

Republik Indonesia. (2014). Undang-Undang Nomor 6 Tahun 2014 tentang Desa. Jakarta: Sekretariat Negara. 